\title{
Challenging Marginalization at the Universities of the Third Age in Poland
}

\author{
Jessica C. Robbins-Ruszkowski \\ Woodrow Wilson International Center for Scholars \\ Weiser Center for Emerging Democracies, \\ University of Michigan
}

\begin{abstract}
Older people in Poland often describe and experience old age as a time in the life course marked by discrimination and marginalization. In this postsocialist context, a still-dominant Cold-War logic links older people to the devalued socialist past and younger people to the present and future of the Polish nation-state. Contemporary media portray old age as defined by physical and mental decline and social isolation. The most visible challenge to such temporal, bodily, and social exclusion occurs through Universities of the Third Age, where older people learn new skills, cultivate hobbies, and explicitly theorize growing old as a positive phase of life. Drawing on twenty months of ethnographic research, this article traces key sociocultural, political-economic, and historical factors that contribute to discrimination against and empowerment of older people in Poland. By analyzing national politics and media representations of old age together with ethnographic data from Universities of the Third Age, this article highlights the practices through which older Poles feel themselves to be transformed in old age-and asks who may be excluded from such practices-thus contributing to gerontological discussions of "active aging" and anthropological understandings of sociality in late life.
\end{abstract}

Keywords: active aging, postsocialism, Universities of the Third Age, Poland.

\section{MARginALIZATION THROUGH NATIONAL HISTORICAL POLITICS}

In contemporary Poland, older people often describe and experience old age as a time in the life course marked by discrimination and marginalization. In the public sphere, older people speak of rudeness on city buses and trams ("no one gives up their seat for us"), and of feeling "transparent" ("przeroczysty") on the street. In the private sphere, older people describe feeling lonely after they retire as their network of social contacts shrinks, losing a sense of purpose outside their family. Some older people go so far as to describe growing old as losing one's personhood. In the media, old age is often portrayed in negative terms, defined by physical and mental decline and social isolation, and often couched in the language of demographic fear (Wilińska and Cedersund 2010, Zierkiewicz and Łysak 2005). This cultural devaluation and marginalization of older people is associated with national political-economic shifts that have occurred during the lifetimes of the oldest generations in Poland, in which older people have become socioeconomically disadvantaged (Calasanti and Zajicek 1997, Synak 2003, Trafiałek 2003). Moreover, contemporary interpretations of the past that link the lifetimes of older people, and especially older women, to a nationalist Catholic understanding of the Polish nation can further exclude older Poles from full inclusion in society.

The most visible challenge to such temporal, bodily, and social exclusion occurs through Universities of the 
Third Age, where older people learn new skills, cultivate hobbies, and explicitly theorize growing old as a positive phase of life. Universities of the Third Age are currently experiencing a "boom" in Poland, with half of the almost 400 Universities of the Third Age nation-wide having been founded in the last ten years. ${ }^{1}$ This increase in Universities of the Third Age is occurring at the same time as European governments are focusing on policies promoting "active aging" as a response to demographic changes (see PerekBiałas et al. 2006 for a discussion of active aging policies in Poland and the Czech Republic; see Boudiny 2013 for a critical analysis of the multiple meanings and uses of active aging).

Universities of the Third Age have a deep history in Poland: the first Polish University of the Third Age was founded in 1975 in Warsaw, only two years after the first-ever University of the Third Age was founded in Toulouse. ${ }^{2}$ Although the specific activities and pedagogical styles vary greatly in Universities of the Third Age worldwide (see Formosa 2012 for a recent global history of Universities of the Third Age), they all share a focus on providing education for older adults in the so-called "third age," or "the span of years between retirement age and the advent of age-imposed limitations" (Weiss and Bass 2002:29; see Laslett 1996 for a canonical explication of the "third age"). In Poland, there are varying models of institutions - some are associated with universities, while others are free-standing organizations - that have varying models of payment and participation, ranging from the nearly free (e.g., 30 USD per year) to the more expensive (e.g., 30 USD for each class). Some people organize their whole lives around the institutions, attending a class or workshop nearly every day, while others attend only one class. Nationwide, over 80 percent of attendees are women, which, in addition to the greater number of older women in the population, can be explained by gendered patterns of sociality and ideologies of the life course, in which women are thought to be most deeply connected to other people from childhood to late life, while men are understood to be more strongly connected to the world of things and nature. ${ }^{3}$

World wide, Universities of the Third Age aim to improve the lives of older people through a range of educational activities. As has been well-established by research that demonstrates improvements in a variety of physical, social, and psychological measures of older people who participate in these programs, these efforts are often quite successful (e.g., Formosa 2012; Kozieł and Trafiałek 2007; Moody 2004; Swindell 1993, 2012; Swindell and Thompson 1995; Zielińska-Więczkowska and Kędziora-Kornatowska 2009; Zielińska-Więczkowska et al. 2011). Despite these improvements in the wellness of participants, however, there is other evidence that critiques these institutions for their age-segregation (Formosa 2012) and their tendency to attract elite members of society (e.g., Formosa 2006, Moody 2004, Wilińska 2012). In the scholarly literature on education in later life, however, Universities of the Third Age are recognized as important institutions through which many older people around the world can work to eliminate the marginalization and exclusion that they face as older persons.

In Poland, these transformative goals are explicitly part of Universities of the Third Age (Ziębińska 2007); these institutions thus pose a productive site in which to investigate how older people in Poland can overcome stereotypes in old age. Moreover, the high prevalence of women at Polish Universities of the Third Age provides a direct contrast to the stereotype of the babcia, or grandmother, in which older women are primarily associated with the family (Wilińska 2010, Wilińska and Cedersund 2010). Polish women who attend Universities of the Third Age thus seem to be overcoming stereotypes that are both general to older people and particular to older women.

In this article, I draw on data from twenty months of ethnographic fieldwork that I conducted in educational and medical institutions in Wrocław and Poznań, two cities in western Poland, from 2006 to 2012, with the longest fieldwork period occurring between 2008 and 2010. The primary educational sites of study were Universities of the Third Age in Wrocław and Poznan, where I attended classes and weekly lectures, interviewed participants and staff, taught conversational English classes, and reviewed institutional archival material. I also conducted interviews with participants in an NGO-run educational program in Wrocław called @ktywny Senior (@ctive Senior). This article draws on the 39 interviews and many hours of observations that I conducted at educational institutions, as well as interviews and observations from my time at the medical institutions where I conducted my fieldwork. ${ }^{4}$ The interviews were open-ended and I tried, as much as possible, to let the interviewee guide the conversation (Briggs 1986). In addition to interviews, I also had more informal unstructured conversations with participants and staff.

I interpret this ethnographic data in the context of national politics and media discussions of aging in an attempt to merge micro- and macro-level perspectives on aging in Poland. By tracing key sociocultural, politicaleconomic, and historical factors that contribute to discrimination against and empowerment of older people in Poland, this article aims to create a holistic discussion of aging in Poland. First, I will analyze two political events of the last decade to demonstrate how popular discourse on the Polish nation links the figure of the old woman with 
that of the Polish nation. Next, I will analyze an influential newspaper series on aging in Poland in which a prominent social psychologist criticized Universities of the Third Age. Then, I will use ethnographic and textual evidence from the University of the Third Age in Wrocław to show how older women perceive their participation in this institution as a response to contemporary discrimination and a lifetime of labor for others. By combining an analysis of popular media with ethnographic observations and interview data, this article both elucidates the nationalpolitical aspects of stereotypes of older people in Poland and describes popular attempts to overcome these stereotypes.

Understanding the discursive links between older people and the Polish nation demonstrates the moral stakes of older people's participation in Universities of the Third Age in Poland. My theoretical perspective is grounded in anthropological studies on personhood, and especially those of Marcel Mauss ([1925]1990, [1935]1985) and T. O. Beidelman ([1986]1993), in which personhood is formed through social relations and cosmological imagination, and is thus inherently moral. Therefore I see the moral personhood of older people in Poland as intimately tied both to discursive imaginations of the Polish nation and to everyday practices of aging. This article highlights the practices through which older Poles feel themselves to be transformed in old age-and asks who may be excluded from such practices-thus contributing to gerontological discussions of "active aging" and anthropological understandings of sociality in late life.

\section{MOHAIR BERETS AND DEFENDERS OF THE CROSS}

Two moments during the last decade demonstrate particularly well the connection between older people and the nation in Poland. Talk about older people in both the media and daily life can become evaluative conversations about the state of the Polish nation. These are often deeply gendered discourses (Graff 2009; McClintock 1996; Mosse 1988). In other words, older women become figures of the nation (see Cohen 1998 for related connections between old women and the nation in India). These two historical moments demonstrate the degree to which the figure of the old woman is associated with a particular nationalist Catholic understanding of the Polish nation.

The first example relates to Polish national elections, which in recent years have shown the extent to which age and generation can index political worldviews. As has been well-documented across eastern Europe, political opposition to the former socialist state sometimes brought about the rise of right-wing nationalism (e.g., Verdery 1993). In postsocialist Poland, denouncing the socialist past is still a common move among far-right politicians, who draw on the historical legacy of partitioned Poland and Soviet rule to champion an independent Polish nation that is ethnically Polish, Catholic, and ardently anti-communist. The strength of this ideology perhaps reached its zenith in Poland in 2005 when the Law and Justice party (Prawo i Sprawiedliwość, or PiS), led by the identical twin brothers Lech and Jarosław Kaczyński, won both presidential and parliamentary elections. PiS came to power on an anti-corruption, anti-communist, and strongly Catholic platform. For PiS, to be a proper Polish citizen is to uphold "traditional" family values, epitomized in the performance of clearly demarcated patriarchal gender roles (Graff 2009). Because PiS did not win a large enough percentage on their own, they had to form a governing coalition; their coalition partners were the League of Polish Families (Liga Polskich Rodzin, or LPR) party, an extremist nationalist religious party, and Self-Defense (Samoobrona, or SO), the so-called peasants' party. Support for these parties among older people was extremely high, especially among those from more rural, eastern regions of Poland. ${ }^{5}$ This coalition government ultimately proved unstable, and PiS lost parliamentary elections in 2007 to the more center-right pro-business Civic Platform (Platforma Obywatelska, or PO) party.

This political instability manifested in generational terms in the months leading up to the 2007 parliamentary elections. The link between older women and the conservative nationalism of PiS took the figure of the moherowe berety (mohair berets). This term refers to the wool caps that many older Polish women wear, and has come to stand for groups of older rural women who support $\mathrm{PiS}$ and listen to the conservative nationalist Catholic radio station Radio Maryja, the flagship member of a media conglomerate run by the controversial, conservative priest Father Tadeusz Rydzyk. ${ }^{6}$ A widely circulated image from the months before the 2007 parliamentary election depicts a large group of older women wearing these hats attending what is presumably a mass, with the added caption "VOTE, or else they'll do it for you!"7 Intended as a get-out-the-vote campaign targeting younger voters, this image demonized elderly women en masse because of their politico-religious views. Another ad urged, "take your grandmother's identity card!" (thereby making it impossible for her to vote). ${ }^{8}$ In both these images, it is not merely older people who are seen as threatening here, but specifically older women. In other words, in the popular imagination in Poland it is particularly older women who are associated with the conservative nationalist views of PiS and Radio Maryja. Significantly, it is when these older women come together as part of a voting bloc that they become dangerous; one older woman who listens to Radio Maryja is harmless, but hundreds of such women are dangerous. 
More recently, the controversies over the placement of a cross following the tragic plane crash in April 2010 that killed 96 people near Smoleńsk, Russia, can also be understood in generational terms. This tragic accident occurred as the president, Lech Kaczyński, and many top governmental officials were traveling to Smoleńsk to mark the 70th anniversary of the massacre of Polish officers in the Katyn forest. It soon became clear that the party of the late president and his supporters understood this as the latest event in Polish national martyrdom. People spoke of a second Katyń and conspiracy theories ran rampant, blaming PO or Russia for the crash (Lech Kaczyński was running for re-election at the time of the crash). The event became cemented as part of the national mythology of suffering when the president and his wife were buried in the crypts of Wawel Cathedral in Kraków, alongside Polish kings. After the crash, public spaces throughout the country were filled with memorials of flowers, candles, pictures, and messages. Outside the presidential palace in Warsaw, girl and boy scouts erected a large wooden cross as a memorial. When the newly elected president (Bronisław Komorowski, from PO) tried to move the cross to a nearby church, people refused to let it be moved. Even though this move had the approval of the Church, people guarded the cross and refused to let it be moved; the deceased president's twin brother, Jarosław Kaczyński, who had just lost the election for president to Komorowski, also supported leaving the cross in the current position. These protests sparked a counter-protest by people who wanted the cross moved. ${ }^{9}$ Media coverage of the events, which lasted for months, depicts those protesting the removal of the cross as older, and those demonstrating for its removal as younger. In August, after a failed attempt at moving the cross to the church, explicit conflict broke out between the two protest groups. The Polish political philosopher Leszek Koczanowicz describes the groups in generational terms:

One crowd consisted of young people who organized a kind of carnival playing popular songs and performing short scenes that in eyes of the second crowd were on the verge of blasphemy, for instance, making a cross out of beer cans. The second crowd consisted largely of older people praying, listening to priests and speakers, and singing religious songs. [2012:822-823]

Although Koczanowicz (2012:823) finds these groups united in their individualist-based rejection of various authorities, I would highlight the generational differences of these groups. Certainly not all who wanted the cross to stay were old, or all who wanted to remove it were young, but given the broader political context of Poland, it is clear that important national ideological differences have generational fault lines.
In both events, older Poles, and especially older women, were central figures in public discourse about the future of the country. This popular dismissal of older Poles as out-of-touch was echoed in conversations I had with Poles of roughly my own age (in their late twenties to thirties), who would explain anti-Semitic, racist, or conservative religious comments made by an older person by saying things like, "these older people just need to die off." "Our society won't move forward until the older generations are gone." However, such comments about anonymous older Poles contrast with the same person's warm feelings towards his or her own grandparents. That is, the animosity towards the anonymous or unknown older person, or the elderly en masse, contrasts with the warmth that people feel for specific older people that they know. In these conversations with Poles of my own age, exactly which part of the past made older people problematic for the national future was not always clear. It was often their association with the nationalist far-right and its exclusionary policies and visions, as described above, but sometimes it was the very fact of their having come of age and worked during the socialist era, leading them to have a socialist-era mentalność, or mentality. Regardless, it was their association with the past that made their future inclusion suspect.

This link between older people and the socialist past, and younger people and the capitalist, democratic, and globalized present and future, I argue, is a key way that older people, exemplified by older women, are made marginal to the present and imagined future of the Polish nation-state. Yet this marginalization of older people exists in other domains besides the explicitly political. In the next section, I will focus on one interview with a prominent Polish psychologist that motivated a series of articles about aging in a leading Polish newspaper. Analyzing this interview serves to demonstrate in more detail the moral stakes of negative perceptions of old age in Poland, which attendees of the Universities of the Third Age attempt to overcome.

\section{“NO COUNTRY FOR OLD PEOPLE"}

The series "Polska to nie jest kraj dla starych ludzi," or "Poland is no country for old people," ran for ten days in Gazeta Wyborcza (Electoral Gazette), Poland's largestcirculating non-tabloid daily newspaper, in November $2008 .^{10}$ The paper of record in Poland since 1989, Gazeta Wyborcza emerged out of the Solidarity movement in the 1980s as the major independent daily newspaper. This series emerged out of a provocative interview with a wellknown psychologist, Wiesław Łukaszewski, on the topic of aging and is one of many such occasional topical reports that Gazeta Wyborcza publishes. ${ }^{11}$ The series consisted 
of 17 articles and 33 letters from readers, published on weekdays for two consecutive weeks. Beginning with a survey on perceptions of old people and an extended interview with Łukaszewski (Wodecka 2008), the articles in the first week focused on the discrimination common to many Poles' experiences of aging, taken to the extreme in a terrifying story about an abandoned old woman, Władysława Baranowska, left to die alone in her apartment (Kasperska 2008). Also including articles about upcoming changes in the social security system, discrimination in the media, an economic comparison of old age today and in the 1970s, recommendations for being healthy in old age, and a manifesto called "Old age is beautiful," the first week presented aging as a largely negative experience, and made clear the newspaper's attempts to change this.

The second week, which included fewer articles and more letters from readers, reported on dire demographic changes and the state of medical care for the elderly in Poland, and described the relationship between elderly people and new technology (e.g., computers, cell phones). Ending with two stories about older people's experiences of discrimination in the workplace, the series seemed to conclude in the same place it started: namely, discrimination. The series seemed to emphatically confirm its title, that indeed, Poland is not a country for old people. By covering such a wide range of topics and encouraging readers to share their experiences (many articles end with the provocation, "Is Poland a country for old people? Write in about your own old age"), the newspaper attempted to create a national dialogue on old age in Poland. ${ }^{12}$

Throughout the articles on aging in Gazeta Wyborcza, a vivid vocabulary emerges to describe aging. For example, a scholar lists some of the negative words used to refer to older women, including "megiera," a word for a nasty, ill-tempered old woman derived from Magaera, one of the Greek Furies, and "mother-in-law" (Zawadzka 2008), which one Polish friend equated with megiera. The use of the word "still" (jeszcze) in survey questions (e.g., "Do I still earn money?" or "What do you still want to do in your life?") signals an expected end to a particular activity or dream (Klimowicz and Sokólska 2008); in other words, asking if one is "still" doing something in old age reveals an expectation that activity might have ceased..$^{13}$ Taken together, these words evoke painful histories, problematic everyday social encounters, and difficult positions within families, all shaded by expectations of decline in old age. This vocabulary is overwhelmingly negative and depressing.

Gazeta Wyborcza presents aging persons in two morally distinct categories. Who was responsible for creating such good, bad, or non-persons, however, remains ambiguous throughout the series. The major difference between these moral categories was determined by levels of activity or social engagement; the many older people portrayed as isolated, lonely, depressed, poor, and ill, are the typical negative examples of growing old, while the few people who are described as active, sporty, and socially engaged are the positive examples of growing old. ${ }^{14}$ The primary distinguishing characteristic between negatively- and positively-presented old persons is whether one is the same or different person than when one was younger; what counts as sameness and difference in personhood is imagined on the basis of activity. If one has the same degree and quality of (mental, physical, and social) activity as when one was younger, one can maintain a continuous personhood. If, however, one's engagement with the world diminishes, shrinking and dwindling until the end of life, then one becomes a different sort of person in old age. This different sort of personhood is a lesser sort of personhood; that is, being less active makes one less fully human than one's more active and younger peers.

But the experiences of Łukaszewski suggest that activity in old age is not enough to stave off such discrimination. As a professional older man who is still working, according to the ideals of active aging, he should have been satisfied and fulfilled. Nevertheless, he experiences intense discrimination. How can independent ideals of self-fulfillment, self-reliance, and flexibility explain his situation?

In an article entitled "When I go rollerblading, the brats yell: to the grave, grandpa!"(Wodecka 2008), Łukaszewski describes various instances in which he has experienced discrimination as an older person. For example, he feels "przezroczysty" ("transparent") on the street, where younger people look through him as if he were not there, and in other public spaces (clubs, stores, parks), ads, and on internet forums. He attributes this to a contemporary culture that privileges a quick pace over a slow one, and in particular, blames Poland's "monopolistic" culture for encouraging discrimination.

Besides, Polish culture is monopolistic, meaning that we have one language, one faith, one system of values. Such cultures are very dogmatic and prone to discrimination. Even in the Polish village there is no respect for the old. In the past, they were the main source of knowledge, but now the television has taken the role of wise old people. The elderly have lost their basic function as carriers of culture. They've become second-class citizens. They've become Untermenschen (sub-human). It seems to me that in the opinion of many young people, an old person belongs to a completely different species. Neither homo nor sapiens. ${ }^{15}$

Łukaszewski's use of the word Untermenschen is striking; meaning 'sub-human' in German, the term is associated with Nazi race science and was used to label 
Slavs (including Poles) and Jews as inferior types of persons, appropriate for extermination. As an older Pole, he was certainly aware of this word's history, and was most likely using it consciously and deliberately. It is hard to imagine a stronger or more damning word for a Pole to use to describe experiences of discrimination, making Łukaszewski's characterization of old age emphatically and unequivocally negative.

The interviewer's response is to suggest not consenting to practices of discrimination, to which the professor says that he himself does not, but that as a group, "old people are socially and economically poor" and therefore afraid. ${ }^{16}$ Łukaszewski attributes this fear to Poles' lack of trust in others, reflected in the lack of trust that dominates the whole of Polish social life. Because older people are afraid, he says, they want to remain anonymous, which is why so many older people are active within the church and in Universities of the Third Age. Neither the church nor Universities of the Third Age expect "acts of personalization" from its participants, Łukaszewski claims. ${ }^{17}$ "Instead the opposite, [they] expect anonymity, depersonalization. That's an excellent niche for old frightened people." ${ }^{18} \mathrm{He}$ describes Universities of the Third Age as places that aim to fill up the endless empty hours of "unfortunate old folks," having nothing to do with actual universities or learning. ${ }^{19}$ He instead suggests that the government fund the education of a few old people at undergraduate universities, where they could study alongside their younger peers, rather than spending their time at so-called universities making pots or tapestries, just so they can feel needed.

The professor emphasizes older people's desire to feel needed in his comments regarding relationships with adult children. The interviewer describes older people whom she knows who support their children and grandchildren financially "so that my kids will have it better," but are really afraid that if they stop caring for their offspring, they will cease being necessary. ${ }^{20}$ The professor responds that such care provides older people with proof of their importance, but that they provide such care out of a sense of duty, rather than real desire. ${ }^{21}$ "It's the language of necessity: I have to be at home because Stefan is coming with the kids and I have to make crepes. They don't say that it's fun or a blessing. The word 'I have to' is the key, it's the testimony to continuous duty, the fulfillment of which is the reason for their usefulness." 22 In other words, Łukaszewski claims that older Poles who care for their kin are doing so to avoid the discrimination and dehumanization that accompanies old age. However, he sees these ties of obligation, evident in the language of necessity, as excluding a genuine desire to care. Given that it is primarily older women who provide care within the family, and that one can simultaneously be obligated to and desire to care, I read Łukaszewski's statements as possibly denigrating the genuine efforts of older women to help their kin.

Łukaszewski thus gives an authoritative voice, as both a professor and a man, to experiences of discrimination in old age. Not easily dismissed or ignored, as a woman or less-educated person might be, by including his perspective early in the series the newspaper reinforces the strength of such negative understandings of old age. Intentionally provocative, Łukaszewski's words prompted several angry letters of response from those who supported Universities of the Third Age, and people at the University of the Third Age in Wrocław were so outraged that they held a special meeting to discuss the professor's incendiary remarks.

\section{THE MORAL PRACTICE OF AKTYWNOŚĆ AT Universities of the Third Age}

The interview with Łukaszewski in the Gazeta Wyborcza series struck a nerve with University of the Third Age słuchacze (attendees) in Wrocław. ${ }^{23}$ His denunciation of Universities of the Third Age as old-age ghettos deeply upset many słuchacze, who felt that they had been misunderstood and misrepresented. On a Thursday afternoon in December 2008, master's-level students studying for their degree in andragogika (adult education) moderated a two-hour discussion with słuchacze in the main meeting room of the University of the Third Age, at the Institute of Pedagogy at the University of Wrocław. Around 30 people attended, mostly słuchacze but also a few students in andragogika. I attended the meeting as part of my fieldwork at the University of the Third Age. Throughout the discussion, słuchacze and students alike extolled the virtues of Universities of the Third Age for the opportunities it provides to create a good old age.

Both older and younger students spoke passionately about their participation in the University of the Third Age, and said that Łukaszewski did not really understand what went on there, for if he did, he could never had categorized it thus. One słuchaczka, who is involved in the administrative work of the University of the Third Age, criticized Łukaszewski for not having a better understanding of what happens at Universities of the Third Age. In her view, słuchacze are "crossing certain barriers" that are not expected of older people: the very act of learning itself, walking up the stairs at the university (she said she had only recently come to see this as a barrier), and being artistic. ${ }^{24}$

Through these activities, słuchacze are defying expectations of their role as older people in society. Despite this słuchaczka's critique of Łukaszewski, he 
redeemed himself in her eyes by discussing the importance of spending time with younger people. She has greatly enjoyed her time in classes and workshops with younger people; these gatherings leave her smiling. Moreover, she thinks that słuchacze can show younger students how to age. She attributes the rudeness towards older people in public as a result of a lack of contact between older and younger people. Through breaking these boundaries of what is expected of them, słuchacze can encourage younger people to think that "this age isn't so terrible," and that "one would like to experience this old age and would like to be old." ${ }^{25}$ An older man also saw part of his role in old age as teaching younger people how to grow old, which he did by encouraging the younger people in the room to read Deepak Chopra's (1993) Aging Body, Timeless Mind, and to cultivate a "strategia" ("strategy") for growing old, in which one should have "aktywność maksymalna" ("maximum activity") in all spheres of life: intellectual, physical, psychological, and moral. ${ }^{26}$ Through such strategies, people can learn to approach old age "with the hope of a life that could be even better and more interesting." ${ }^{27}$ His comments were met with a loud round of applause.

Throughout this discussion, older and younger people alike reiterated the moral aspect of Universities of the Third Age. One student spoke of how inspiring it was for her to see older people participating in such a diverse range of activities; from this she has learned that how one grows old is one's choice. "I am really glad that you are showing us, especially young people, that everything depends on us. And that it's really our decision what this phase of our life will be like." ${ }^{28}$ Another student critiqued Łukaszewski for his positive portrayal of the West because that student had spent time as a child in the U.S., where his friends did not even know their grandparent's first names. He took this as a sign of the weakness of kin ties in the West, and contrasted it to the strength of kin ties in Poland. Here, he said, "these ties exist between the young and old generation - this is also our capital, on which we can work for the future." ${ }^{\prime 29}$ This comment was also met with applause.

This discussion crystallized much of what I see as key to how słuchacze in both Wrocław and Poznań understand their participation in the University of the Third Age. Through practices of aktywność (activity), older people no longer have to be the stigmatized, isolated adults described in Gazeta Wyborcza. Rather, through the lectures and classes at the University of the Third Age, people can transform themselves into moral exemplars for the younger generation. Becoming such a moral exemplar occurs through the practice of aktywność across domains of life: physical, mental, spiritual, and social. This ideal of setting an example for younger people is accompanied by the intense determination of słuchacze to make aging a positive experience, in ways that contrast with their lives until this time. Mostly well-educated upper-class women who had retired from jobs as teachers, accountants, or medical workers, słuchacze described their lives before their participation in the University of the Third Age as busy with work and family. At the University of the Third Age, these women told me that they can finally robić coś dla siebie, or do something for oneself.

The practice of aktywność is explicitly theorized and promoted by the leaders of Universities of the Third Age and other "active" aging programs. In the words of Walentyna Wnuk, a former director of the University of the Third Age in Wrocław, "we have to learn how to age well" (2009:5). ${ }^{30}$ A current adviser to the mayor on seniors' affairs, she is trained as a "cultural organizer" ("kulturalny animator") and sees herself as skilled in helping people achieve their potential. She is active in EFOS (European Federation of Older Students at Universities), an international coalition of Universities of the Third Age. This group's goals, as described on their English-language brochure, are to "activate elderly people, integrate them in the learning society and stimulate the intercultural dialogue as a transfer medium. In this way we will contribute to an active citizenship of the elderly people." Wnuk aims to foster such "active citizenship" through organized trips to Brussels and Strasbourg in which UTW students meet their European Parliament representative.

According to Wnuk, stuchacze described these trips as transformative because they changed the minds of people who had opposed Poland's EU membership. Older Poles need to learn to be "open," she said, in contrast to the socialist past, when society, and therefore persons, were "closed." She sees the University of the Third Age as helping to create a new model of aging and a new type of person-a "Eurosenior" - who better fits with the current world order. A binary Cold War logic underpins this comment, in which a closed, socialist Poland is opposed to an open, capitalist, democratic western Europe. The chance for Polish retirees to meet with their European Parliament representative or travel to Brussels is part of a teleology in which the West remains the ultimate goal.

Although Universities of the Third Age often offer a variety of classes and workshops, ranging from practices often associated with older people (e.g., embroidery, cabaret groups) to those more commonly associated with youth (e.g., learning foreign languages, volleyball), it is the latter sort of activity which carries ideological weight at the Universities of the Third Age, both for the słuchacze and the institutions. Currently, English language and computer classes are among the most popular courses of study. These topics fit well with the political economy 
and culture of contemporary Poland, where English and computer skills are requirements for many jobs and symbolize the capitalist, globalized present. Older people who speak English (instead of the Russian that they were forced to learn as children during state socialism) and who can use computers thus have access to the symbolic capital associated with these practices. However, both English and computer skills are also useful for the many older Poles who have family living abroad in Englishspeaking countries. That is, many older Polish people want to learn English to communicate with non-Polishspeaking kin via computer programs such as Skype (the verb "skajpować," or "to Skype" has become common in spoken Polish). This practical use is at least as important as the political economic and cultural significance of these skills, suggesting the need to focus analytic attention on the social dimensions of the Universities of the Third Age.

One retired teacher, Jolanta, who has attended the University of the Third Age for over eight years, in many ways seems to be the ideal example of an older person who has been thus transformed through attending the University of the Third Age. Jolanta began attending the University of the Third Age after she had been retired for ten years and both her children moved away. Widowed, Jolanta became lonely and sought out the University of the Third Age as a way to overcome this loneliness. Her strategy for aging was to fill in what she felt she had missed out on during her life; for example, she learned to swim at age 70. Jolanta describes her experience there as providing her with a "druga rodzina," or "second family." This "family" gives her support, companionship, and above all, she says, advice for coping with health problems. Jolanta's "second family" now takes up her time in a way that prevents her from seeing her kin; she regrets that she can only visit her daughter in England during breaks in the University of the Third Age's school year, and that she does not often visit her husband's or parents' graves because of the time she spends at the University of the Third Age.

Jolanta is typical of many of my research participants at the University of the Third Age. These women found in the University of the Third Age a way to form new social relations to overcome the loneliness accompanying retirement, and often, widowhood (cf. Wilińska 2012). They describe retirement and aging as negative experiences that have been improved through participating in the University of the Third Age, through learning new skills and learning how to cultivate a sense of personhood in old age. Yet, although Jolanta was proud of the new skills she had learned through the University of the Third Age, it was the new social relations that seemed most important to her. In other words, Jolanta's transformation from a lonely older person into an active senior occurred not only through the kinds of skills and international cultural groups encouraged by institutional leaders, but also, and perhaps even primarily, through the cultivations of new ties of relatedness (Carsten $2000,2004)$ that supplanted her previous kin ties. This significance of social relations contrasts both with the language of individual empowerment that was evident in the discussion at the University of the Third Age about Łukaszewski's comments, and with popular discourse that links older people to national frameworks. Rather, the significance of close friendships and new social relations for Jolanta and other women like her suggests that greater anthropological attention should be paid to the social dimensions of "active aging" and empowerment.

\section{THE LIMITS OF EMPOWERMENT}

Jolanta's experiences highlight social dimensions through which older people in Poland can combat dominant cultural stereotypes of aging. Słuchacze find these institutions to be empowering; older women can regain personhood lost through retirement, widowhood, and negative stereotypes. However, these empowering experiences are not equally available to all older people. Health and especially mobility are key factors determining access to the Universities of the Third Age (see Formosa 2012:14 for a critique of Universities of the Third Age for their exclusion of those with disabilities). Poland's urban spaces are difficult, if not impossible, to navigate for those with mobility impairments (see Bujacz et al. 2012 for a study of the city of Poznan according to the needs of older people, and Phillips 2011 for an ethnographic study of mobility and disability in Ukraine), to say nothing of multi-story apartment buildings with no elevators. For people who do not have the bodily capabilities to attend the Universities of the Third Age on their own, or other socioeconomic resources to help them do so, such institutions remain essentially off-limits. Moreover, the rhetorical ideology of "active aging" is not equally available to all, as it relies heavily on 19th-century bourgeois ideals of personhood in which leisure time and the pursuit of certain hobbies become markers of high class status (see Jakubowska 2012 and Robbins 2013 for a further discussion of the legacy of the 19th-century among older people in contemporary Poland). In other words, the moral ideology of "active aging" produces and reflects different classes of persons and bodies. In order to make concrete the socioeconomic aspects of the possibilities for "active aging" in Poland, I will present a final example from the Gazeta Wyborcza series on aging.

It is impossible to imagine the retired professors and engineers of the Gazeta Wyborcza series, so vibrant, busy, and healthy, in the position of Władysława Baranowska, an older woman whose tragic old age and death is detailed in 
a long article in the series. This older woman was brought to the hospital "in a state of extreme emaciation, neglected, with bedsores, with white worms in her wounds." ${ }^{31}$ The admitting doctor remarked, "Only homeless people come to us in such a state." 32 The article describes a failed network of care that led to this end; despite a daughter living nearby, paid caregivers, and multiple trips to the hospital, nothing prevented Ms. Baranowska from "[coming] to such an end as if she were trash," in the words of her neighbor. ${ }^{33}$ This neighbor blamed Baranowska's daughter for neglecting her mother, while also recognizing that their shared apartment building was not a suitable environment for an older person living alone. Baranowska's son-inlaw, meanwhile, blamed three different government institutions (the city social aid department, the hospital, and long-term care institutions) for failing his mother-inlaw. There was no clear way for Ms. Baranowska to receive adequate care.

This damning article presents a jumbled and confusing maze of institutions and individuals that are supposed to provide care, in which meager personal, familial, institutional, and systemic resources do not add up to a dignified life or death for Władysława Baranowska. ${ }^{34}$ As a reader, it is hard to know where responsibility should lie; one sees genuine efforts and missteps made by each actor. Each health-care institution ultimately blames Baranowska's daughter and family for her condition, while the family blames the institutions. The healthcare system appears fragmented and poor, with no one doctor or institution assuming ultimate responsibility for the patient's care. The diagnosis of "old age" in Ms. Baranowska's chart suggests that at least some medical personnel consider old age itself a disease, raising the question of how earnest any medical treatment of an older person can be, since they will still have the disease of "old age." The doctor's comment that he only sees homeless people arrive at the hospital in such a state suggests the existence of a group of people for whom such a bodily state is expected. How can adequate care be provided when the assumption is that old age is a disease, or that homeless people will have worms crawling in their wounds? What kind of old age is possible for such people?

Indeed, throughout the articles and letters that comprise the Gazeta Wyborcza series, persons of different social classes appear, yet class status is rarely explicitly discussed in the moralizing discussions on successful and active aging. That is, those who brag about their own successes or encourage such successes in others do not address the financial or social conditions that play a role in their own successes, and in the "failures" of others. Those who share financial and social hardships rarely voice concerns about active aging. While these disjunctions are less overtly dramatic than the shocking details of Ms. Baranowska's life and death, they all skirt the same issues: namely, the ideals of a successful, active, old age are incompatible with the everyday lives of many older Poles, who, for reasons having to do with finances, social relations, and bodies cannot live according to the ideals of active aging. These older people can be ignored as objects of care, as indicated by the surgeon's comment about the homeless, fall through the cracks of a broken system of relations, as in the case of Władysława Baranowska, or be discriminated against by their peers, families, and society, as in the examples of the many older people who wrote letters expressing sadness and loneliness. All become less fully human in their deviations from the ideals of active aging. Is there any role for Universities of the Third Age in such cases? Might the transformative role of social relations for women such as Jolanta have some relevance for women such as Ms. Baranowska? Seeking commonalities at the level of everyday practices of relatedness (Carsten 2000, 2004) across such diverse class and ideological contexts suggests that there might be even more possibilities for combatting negative stereotypes of old age in Poland. Such attention to relatedness could shift the focus of debate from individuals to collectives, as some scholars have suggested (e.g., Katz and Laliberte-Rudman 2004). That is, sidestepping conversations about "Euroseniors" and their implicit class hierarchies could provide ways for older Poles to forge new forms of personhood that are not so closely aligned with entrenched socioeconomic and national modes of belonging.

In this article, I have tried to frame Polish Universities of the Third Age in the context of national historical politics and public conversations about old age. From this macro-perspective, women who attend Universities of the Third Age can be understood as challenging dominant stereotypes of old age in general, and of old women in particular, through their practices of aktywność. Institutional focus on Poland's membership in the EU can be understood as an attempt to overcome negative associations of older people with the socialist past, while learning new hobbies and skills can be understood as an attempt to overcome negative stereotypes of old age as a time of decay. However, the example of Ms. Baranowska suggests that the bourgeois ideals implicit in the activities and rhetoric of Universities of the Third Age, as well as the bodily health required to attend, can exclude many older people from access to a culturally-sanctioned good old age. Yet the new social relations that many słuchacze form at Universities of the Third Age suggest that ties of relatedness may be as helpful in combatting negative stereotypes of old age as are the practices or ideals of the Universities of the Third Age themselves. A renewed focus on the sociality of old age, then, may help to show links across socioeconomic divisions and help to expand the 
possibilities for personhood among the most marginal in society.

\section{Acknowledgements}

This research was funded by the Wenner-Gren Foundation (Dissertation Fieldwork Grant \#7736), the National Science Foundation (DDRIG \#0819259), and several units at the University of Michigan. This article benefited from the constructive suggestions and creative vision of Lindsay DuBois, Liesl Gambold, the anonymous reviewers, and Jason Danely. I am grateful to the Universities of the Third Age in Poznan and Wrocław for making this research possible by generously welcoming me into their worlds.

\section{Notes}

1. (accessed 6 June 2013). See the recent study "Zoom http:// zoomnautw.pl/wp-content/uploads/2012/05/Informacja-prasowa_ ZOOM_na_UTW.pdfna UTW" for a comprehensive overview of the activities of the Universities of the Third Age in Poland.

2.International Association of Universities of the Third Age, http:// www.aiu3a.com/origins.html (accessed 1 April 2013).

3.This information on gendered ideas of the life course comes from the author's long-term ethnographic fieldwork in Poland, and is also supported by the research conducted as part of the project "Zoom na UTW" (Towarzystwo Inicjatyw Twórczych"ę" 2012:46). Other possible explanations for the predominance of women at Polish Universities of the Third Age are the better health of older women as compared to older men, the later retirement of men, the predominance of retired teachers at Universities of the Third Age and the feminization of the teaching profession in Poland (Towarzystwo Inicjatyw Twórczych “ę" 2012:46-50), and cultural understandings of men's importance solely in the domain of paid labor and of old men as weak (Wilińska 2012:299-300). Additionally, it should be noted that the feminization of Universities of the Third Age is not limited to Poland (see Williamson 2000 for a discussion of women's participation in an Australian University of the Third Age, and Wilińska 2012 for a comparison of this case with Poland).

4. The medical institutions included a small Catholic-run rehabilitation center, a larger state-run home for the chronically physically disabled, and a day center for people with Alzheimer's disease.

5. See RMF24 2005 for a Polish-language summary of exit polling.

6. Other media outlets include Telewizja Trwam (I Persist Television) and Nasz Dziennik (Our Daily).

7. „GŁOSUJ, albo one zrobią to dla Ciebie!” "One” is the feminine third-person plural form, indicating that this is specifically directed towards women.

8. See http://www.nytimes.com/2007/10/21/world/europe/21poland. $\mathrm{html}$ ?pagewanted=all\&_r=0 for an English-language discussion of this generational conflict and to see a video clip of the ad. The rock band Big Cyc also had a song entitled "Moherowe berety"; see https://www.youtube.com/watch?v=YjI_uNiGwDQ (accessed 13 May 2013) for a video of the song, which features many images of "moherowe berety" and the conservative politicians that they are thought to support.

9. See Porter-Szücs 2011:201-202 for a discussion of these events in terms of the relationship between PiS and the Church. See the 16 December 2011 edition of "This American Life" (http://www. thisamericanlife.org/radio-archives/episode/453/transcript, accessed 25 August 2012) for an English-language popular media description of the controversies after the plane crash in April 2010. See Zubrzycki 2006 for an analysis of a past controversy at Auschwitz about the placement of crosses

10. http://www.zkdp.pl/, accessed 14 October 2011. The tabloid Fakt has been outselling Gazeta Wyborcza since at least January 2010. 11. June 2011, Marzena Kasperska, personal communication.

12. "Czy Polska to jest kraj dla starych ludzi? Napisz o swojej starości"

13. "Czy jeszcze dorabiam?" "Co chce pani/pan jeszcze w życiu zrobić?" (Klimowicz and Sokólska 2008). See also Janelle Taylor's 2008 article in which she discusses the common use of "still" to describe the abilities of people with Alzheimer's disease. The usage of "still" in Gazeta Wyborcza to describe older people without dementia is an example of the fuzzy boundaries between "normal" and "pathological" aging.

14. See Katz and Laliberte-Rudman 2004 for a discussion of exemplars of old age and retirement in the Canadian press.

15. "Poza tym polska kultura jest monopolistyczna, to znaczy, że mamy jeden język, jedno wyznanie, jeden system wartości. Takie kultury są bardzo dogmatyczne i skłonne do dyskryminacji. Nawet na wsi polskiej nie ma szacunku dla starych. W przeszłości to oni byli głównym źródłem wiedzy, ale teraz rolę mądrych starców przejął telewizor. Starzy utracili podstawową funkcję nosicieli kultury. Stali się drugorzędnymi obywatelami. Stali się Untermenschen. Mam wrażenie, że zdaniem wielu młodych ludzi człowiek stary należy do zupełnie innego gatunki. Ani homo, ani sapiens" (Wodecka 2008).

16. "są to ludzie biedni ekonomicznie i społecznie"

17. "aktów personalizacji"

18. "Wręcz przeciwnie, oczekuje anonimowości, depersonalizacji. To jest doskonała nisza dla starych przestraszonych ludzi."

19. "nieszczęśni starcy"

20. "by dzieci miały lepiej"

21. "Ta troska to dokumentowanie swojej ważności."

22. "To jest język konieczności: ja muszę być w domu, bo przyjdzie Stefan z dziećmi i ja muszę zrobić naleśniki. Nie mówią, ze to frajda, ze szczęście. Słowo 'muszę jest kluczem, jest świadectwem nieustannej powinności, których spełnianie jest dowodem użyteczności."

23. Following local usage, I use słuchacze throughout this article to refer to participants of the University of the Third Age. Its English translation would be "auditors," which shares the connotation of listening (the Polish term could also be translated as "listeners") but the Polish term does not share the English meaning of inspection.

24. "przekraczamy pewne bariery."

25. "ten wiek nie jest taki straszny, i chciałoby się przeżywać ta starość, i chciałoby się być starą."

26. The Polish edition of Aging Body, Timeless Mind was published in 1995 as Życie bez starości, which, back-translated into English, would be A Life Without Old Age.

27. “...z taką nadzieją na może jeszcze ciekawsze lepsze życie."

28. "Bardzo cieszę się, ze państwo pokazują nam, szczególnie osobom młodym, że wszystko zależy od nas. I tak na prawdę jest naszą decyzją jaki będzie ten etap w naszym życiu."

29. "Istnieją te więzi, między młodym i starym pokoleniem - to też jest jakiś nasz kapitał, na którym możemy pracować na przyszłość." 30. “dobrego starzenia musimy się uczyć," Wnuk, Walentyna. 2009. „Późna dorosłość to czas pomyślny.” Kurier UTW: nieregularnik Uniwersytetu Trzeciego Wieku. Wrocław: Uniwersytet Trzeciego Wieku. 16:5.

31. "Przywieziona w stanie skrajnego wyniszczenia, zaniedbana, $\mathrm{z}$ odleżynami, w ranach białe robaki" (Kasperska 2008).

32. "W takim stanie trafiali do nas tylko ludzie bezdomni."

33. "Koniec miała, jakby śmieciem była."

34. See Cohen 1998:81-82 on the trope of abandonment of older people. 


\section{REFERENCES}

Beidelman, T. O.

[1986]1993 Moral Imagination in Kaguru Modes of Thought. Washington Smithsonian Institution Press.

Boudiny, Kim

2013 'Active Ageing': From Empty Rhetoric to Effective Policy Tool. Ageing \& Society 33(6):1077-1098.

Briggs, Charles L.

1986 Learning How to Ask: A Sociolinguistic Appraisal of the Role of the Interview in Social Science Research. Cambridge: Cambridge University Press.

Bujacz, Aleksandra, Nina Skrzypska, and Anna Maria Zielińska

2012 Publiczna przestrzeń miejska wobec potrzeb seniorów. Przykład Poznania [Public urban space towards seniors' needs. Example of Poznań city]. Gerontologia Polska 20(2):73-80.

Calasanti, Toni M., and Anna M. Zajicek

1997 Gender, the State, and Constructing the Old as Dependent: Lessons from the Economic Transition in Poland. The Gerontologist 37(4):452-461.

Carsten, Janet

2000 Introduction: Cultures of Relatedness. In Cultures of Relatedness: New Approaches to the Study of Kinship. Janet Carsten, ed. Pp. 1-36. Cambridge/New York: Cambridge University Press.

2004 After Kinship. New York: Cambridge University Press.

Chopra, Deepak

1993 Aging Body, Timeless Mind. New York: Three Rivers Press.

Cohen, Lawrence

1998 No Aging in India: Alzheimer's, the Bad Family, and Other Modern Things. Berkeley: University of California Press.

Formosa, Marvin

2006 A Bourdieusian Interpretation of the University of the Third Age in Malta. Journal of Maltese Education Research 4(2):1-16.

2012 Four Decades of Universities of the Third Age: Past, Present, Future. Ageing \& Society:1-25.
Graff, Agnieszka

2009 Gender, Sexuality, and Nation--Here and Now:

Reflections on the Gendered and Sexualized Aspects of Contemporary Polish Nationalism. In Intimate Citizenships: Gender, Sexualities, Politics. Elżbieta Oleksy, ed. Pp. 133-146. New York: Routledge.

Jakubowska, Longina

2012 Patrons of History: Nobility, Capital and Political Transitions in Poland. Burlington, VT: Ashgate Publishing Company.

Kasperska, Marzena

2008 Koniec miała, jakby śmieciem była [She came to such an end as if she were trash]. In Gazeta Wyborcza. Warszawa. November 19.

Katz, Stephen, and Debbie Laliberte-Rudman

2004 Exemplars of Retirement: Identity and Agency between Lifestyle and Social Movement. In Old Age and Agency. Emmanuelle Tulle, ed. Pp. 45-65. Hauppage, NY: Nova Science Publishers, Inc.

Klimowicz, Joanna, and Ewa Sokólska

200840 starych ludzi [Forty Old People]. In Gazeta Wyborcza. Warszawa. November 18.

Koczanowicz, Leszek

2012 The Politics of Catastrophe: Poland's Presidential Crash and the Ideology of Post-Postcommunism. East European Politics and Societies and Cultures 26(4):811828.

Kozieł, Dorota, and Elżbieta Trafiałek

2007 Kształcenie na Uniwersytetach Trzeciego Wieku a jakość życia seniorów [Assessing the influence of the studying at the University of the Third Age on life satisfaction of elderly people]. Gerontologia Polska 15(3):104-108.

Laslett, Peter

1996 A Fresh Map of Life: The Emergence of the Third Age. London: Macmillan Press, Ltd.

Mauss, Marcel

[1925]1990 The Gift: The Form and Reason for Exchange in Archaic Societies. W. D. Halls, transl. New York: W. W. Norton.

[1938]1985 A Category of the Human Mind: The Notion of Person, the Notion of Self. In The Category of the Person: Anthropology, Philosophy, History. Michael Carrithers, Steven Collins, and Steven Lukes, eds. Pp. 1-25. Cambridge: Cambridge University Press. 


\section{McClintock, Ann}

1996 "No Longer in a Future Heaven": Nationalism, Gender, and Race. In Becoming National: A Reader. Geoff Eley and Ronald Grigor Suny, eds. Pp. 104-123. New York: Oxford University Press.

Moody, Harry R.

2004 Structure and Agency in Late-Life Learning. In Old Age and Agency. Emmanuelle Tulle, ed. Pp. 29-43. Hauppage, NY: Nova Science Publishers, Inc.

Mosse, George L.

1988 Nationalism and Sexuality: Middle-Class Morality and Sexual Norms in Modern Europe. Madison: University of Wisconsin Press.

Perek-Białas, Jolanta, Anna Ruzik, and Lucie Vidovićová

2006 Active Ageing Policies in the Czech Republic and Poland. International Social Science Journal 58:559-570.

Phillips, Sarah D.

2011 Disability and Mobile Citizenship in Postsocialist Ukraine. Bloomington: Indiana University Press.

Porter-Szücs, Brian

2011 Faith and Fatherland: Catholicism, Modernity, and Poland. New York: Oxford University Press.

RMF24

2005Sondażowewynikiwyborów prezydenckich[Polling results of presidential elections]. Electronic resource: http://www.rmf24.pl/fakty/polska/news-sondazowewyniki-wyborow-prezydenckich,nId,78289 accessed 25 August 2013.

Robbins, Jessica Choate

2013 Personhood in Places: Aging, Memory, and Relatedness in Postsocialist Poland. Ph.D. dissertation, Department of Anthropology, University of Michigan.

Swindell, Richard

1993 U3A (the University of the Third Age) in Australia: A Model for Successful Ageing. Ageing \& Society 13(2):245-266.

2012 Successful Ageing and International Approaches to Later-Life Learning. In Active Ageing, Active Learning: Issues and Challenges. Gillian M. Boulton-Lewis and Maureen Tam, eds. Pp. 35-63. Dordrecht: Springer Science + Business Media.
Swindell, Richard, and Jean Thompson

1995 An International Perspective on the University of the Third Age. Educational Gerontology 21(5):429-447.

Synak, Brunon, ed.

2003 Polska starość [Polish old age]. Gdańsk: Wydawnictwo Uniwersytetu Gdańskiego.

Towarzystwo Inicjatyw Twórczych"ę"

2012 "Zoom na UTW": Raport z badania ["Zoom to the UTW": Research report]. Warszawa. Electronic resource: http://zoomnautw.pl/wp-content/uploads/2012/05/ Zoom_na_UTW_RAPORT_calosciowy_www.pdf accessed 6 August 2013

Trafiałek, Elżbieta

2003 Polska starość w dobie przemian [Polish old age in an era of transformation]. Katowice: Śląsk Wydawnictwo Naukowe.

Verdery, Katherine

1993 Whither "Nation" and "Nationalism"? Daedalus 122(3):37-41.

Weiss, Robert S., and Scott A. Bass

2002 Editors' Introduction to Chapter 2. In Challenges of the Third Age: Meaning and Purpose in Later Life. Robert S. Weiss and Scott A. Bass, eds. Pp. 29-30. New York: Oxford University Press.

Wilińska, Monika

2010 Because Women Will Always Be Women and Men Are Just Getting Older: Intersecting Discourses of Ageing and Gender. Current Sociology 58(6):879-896.

2012 Is There a Place for an Ageing Subject? Stories of Ageing at the University of the Third Age in Poland. Sociology 46(2):290-305.

Wilińska, Monika, and Elisabet Cedersund

2010 "Classic Ageism" or "Brutal Economy"? Old Age and Older People in the Polish Media. Journal of Aging Studies 24:335-343.

Williamson, Alan

2000 Gender Issues in Older Adults' Participation in Learning: Viewpoints and Experiences of Learners in the University of the Third Age (U3A). Educational Gerontology 26:49-66. 
Wodecka, Dorota

2008 Kiedy jeżdżę na rolkach, smarkaczy krzyczą: dziadek do piachu! [When I go rollerblading, the brats yell: to the grave, Grandpa!]. In Gazeta Wyborcza. Warszawa. November 17.

\section{Zawadzka, Anna}

2008 Dyktatura młodych twarzy [The dictatorship of young faces]. In Gazeta Wyborcza. Warszawa. November 20.

Ziębińska, Beata

2007 Uniwersytety Trzeciego Wieku jako instytucje przeciwdziałające marginalizacji osób starszych [Universities of the Third Age as institutions counteracting the marginalization of older persons]. Doctoral dissertation. Wydział Nauk Społecznych, Uniwersytet Ślaski. Katowice.

Zielińska-Więczkowska, Halina, Waldemar Ciemnoczołowski, Tomasz Kornatowski, and Kornelia Kędziora-Kornatowska

2011 Poczucie koherencji a satysfakcja życiowa słuchaczy Uniwersytetu Trzeciego Wieku [Sense of coherence and life satisfaction in students of the University of the Third Age]. Gerontologia Polska 19(2):119-125.

Zielińska-Więczkowska, Halina, and Kornelia KędzioraKornatowska

2009 Jakość starzenia się i starości w subiektywnej ocenie słuchaczy Uniwersytetu Trzeciego Wieku [Quality of ageing and old age in personal opinions of the members of University of the Third Age]. Gerontologia Polska 17(3):137-142.

Zierkiewicz, Edyta, and Alina Łysak, eds.

2005 Starsze kobiety w kulturze i społeczeństwie [Older women in culture and society]. Wrocław: MarMar.

Zubrzycki, Genevieve

2006 The Crosses of Auschwitz: Nationalism and Religion in Post-Communist Poland. Chicago: University of Chicago Press. 